\title{
Innovation Towards The Effectiveness of Governance
}

\author{
Yanhar Jamaluddin \\ Post Graduate Faculty of Social and Political Sciences \\ Padjadjaran University, Bandung, Indonesia \\ Lecturer Faculty of Social and Political Sciences, Islamic \\ University of North Sumatera, Indonesia \\ yanhar15001@mail.unpad.ac.id / yanharja-ii@uisu.ac.id
}

\author{
Budiman Rusli \\ Padjadjaran University \\ Bandung, Indonesia
}

\author{
Asep Sumaryana \\ Padjadjaran University \\ Bandung, Indonesia
}

\author{
Rd. Achmad Buchari \\ Padjadjaran University \\ Bandung, Indonesia
}

\begin{abstract}
The implementation of post-reform democracy is marked by direct election of regional heads by the people. This becomes the starting point of changing the paradigm of government towards producing a leader with good leadership. On the other hand the elected regional head is required to innovate to realize the effectiveness of governance, through the provision of services that satisfy the public.

This article aims to identify several innovations in realizing the effectiveness of governance in Indonesia. Innovations include: a. The policies are prepared, Agreed and stipulated together with the Regional Head and DPRD, b. Policies prepared in accordance with the will of the people and can be implemented into reality, c. Alignment of regional policy with the center, $d$. Transformative political leadership, and e. Management control of work plans and programs.
\end{abstract}

Keywords_Innovation; Effectiveness; Governance

\section{INTRODUCTION}

The nomination to participate in the election of regional heads in the reform era is done through party channels and individual channels. The party line is the mechanism by which the candidate for Head of Region is nominated through a political party, whereas the individual path is the mechanism by which the candidate nominates independently without party support. This individual path chosen by the candidate of Head of Region one of them caused by distrust of candidate to political party. Each choice, the path of a political party or an individual path, has political consequences. "The political consequences consist of predicted consequences (unwanted consequences) and unintended consequences" (Surbakti, Kompas, 31/03/2016). The consequences are parliamentary support for established policies and programs.

Indeed for the people, the arena of election of the Regional Head is to seek and determine a leader for leadership (Utomo,
2009: 104); That is a Head of Region whose existence (physical, moral, mental, educational, knowledge, experience, etc.) is above the average society. With the advantages of the Head of Region will be viable to lead the community and the region, especially to balance the Trust Approach and Trait Approach. This is where the importance of leadership dimensions related to political aspects.

This phenomenon reflects the existence of political noise to the role of the Regional Head in running the government, especially demanded to innovate to realize the effectiveness of government. This situation also directly implies the quality of service to the community in the region. The public demand for quality service is the right of citizens to be provided by the government, and on the contrary public service is a duty that must be implemented by the government. That means the position of the citizens has changed in getting his rights. As stated by Kei Ho and Coates (2002) in Dwiyanto (2005: 189) "The way of view about the position of the public in obtaining public services from the original as a customer then becomes the owner has a more strategic meaning for local government".

Head of Region as the head of the regional apparatus organization, it is necessary to realize that service to the citizens is an obligation that should be prioritized (without having to be asked), and services should not be ignored because of political interests. It is proper that the Head of Region and the apparatus in a professional manner to innovate prioritize the interests of meeting the needs of the citizens rather than the interests of the group. The fulfillment of the needs of the citizens to be a proof of quality of service and a measure of the assessment of the effectiveness of the Head of the Region to organize the government.

Based on the above background, this article is structured to identify what innovations can be made to realize the effectiveness of governance in the Region. 
The method used to analyze this topic is literature analysis and phenomenon, while the data collected consist of primary data and secondary data. Primary data obtained through observation by observing the phenomenon that occurs, while secondary data obtained through literature or documents

Data analysis is done qualitatively, which means to describe the data quality in the form of a regular sentence, sequential, logical, not overlapping and effective in accordance with the topic of study so as to facilitate the understanding and interpretation of data. The results of the analysis aim to generate innovative ideas toward the effectiveness of government

\section{LITERATURE REVIEW}

A. Innovation

Today, one of the ways to own and maintain competitive advantage is innovation and improvement (Sedarmayanti 2000: 154). Innovation is an attempt to find the latest way of combining some thoroughly (Gibson, 1998: 76). So innovation means presenting something different, by creating new combinations. Such changes are a necessary part of keeping the organization dynamic. Innovation does not mean patchwork improvements and small and small additions. Innovation is the lifeblood of an organization, and innovation requires a mix of creativity, clear thinking and problem-solving skills. Successful innovation must be supported through the organization's strategic vision. There needs to be a strategic vision that drives innovation, and the organization must have something that differentiates it from other organizations, and the organization must continue to strengthen that. The emergence of an innovation also requires thought and behavior to work closely together. Therefore, top management must create a climate that allows leaders to have scope to develop new ideas and resources to implement the idea.

Thus the demand towards absolute change must be done, and one of them is to encourage the emergence of new innovations or ideas whose purpose is to enhance the competitiveness of the organization to make changes, especially in achieving its economic goals, political goals or social objectives (Sedarmayanti). Peter Senge points out that there are three driving forces, which if one of them is implemented may be enough to make significant changes, both in management and in organizations. The three driving forces are: Technology, Globalization, the most challenging force (linked to unprecedented growth). Described by Peter Senge; with the interaction between these three forces will cause profound changes.

\section{B. Definition and Measurement of Effectiveness}

Effectiveness is literally derived from the word effective, which means purpose, or in other words effectiveness closely related to the goal or achievement of goals better. According to Etzioni (in Indrawijaya, 2000: 12) " Effectiveness is an attempt to measure the extent of success of an organization in achieving goals ". While Sedarmayanti (2000: 185-186), " Dimension of effectiveness relates to the achievement of maximum performance, in the sense of achieving targets relating to quality, quantity and time ". Meanwhile, according to Bernard (in Gibson, Ivancevich, et.al, 2007: 38) affirmed " Effectiveness is the achievement of goals of a joint effort. The degree of achievement shows the degree of effectiveness ". Based on the above opinion, the effectiveness is viewed as the achievement of the organization's goals in general and the achievement of output, growth or productivity that has been determined.

Furthermore Gibson, Ivancevich, et.al, (2007: 29-32) asserts that in the perspective of effectiveness, managers and others interested in how organizations can effectively focus on one or all three perspectives. First - individual effectiveness, which emphasizes the performance of tasks of employees or members of the organization. Managers routinely assess individual effectiveness through a process of achievement evaluation to determine who will receive pay, promotions, and other fees available within the organization. Secondly - that individuals rarely work alone, in isolation from other colleagues in the organization. Usually employees work in group form so that still another perspective of effectiveness is needed, that is group effectiveness. The simple group effectiveness according to Gibson, Ivancevich, et.al, is the sum of the contributions of all members. Third Perspective - is organizational effectiveness. Organizational effectiveness consists of individual effectiveness and group effectiveness.

Based on this perspective effectiveness can be described as follows:

Figure 1: Three Perspectives of Effectiveness

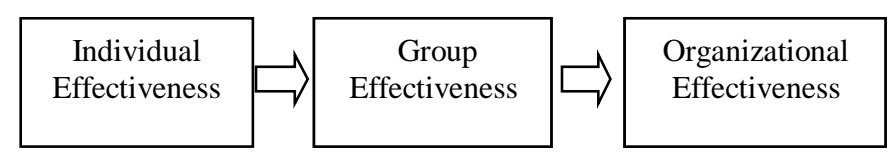

Source: Gibson, Ivancevich, et.al (2007: 32)

Based on the picture 1 can be interpreted that the three perspectives of effectiveness are synergized with each other; group effectiveness depends on individual effectiveness, and organizational effectiveness depends on individual effectiveness and group effectiveness. The relationships between the three will vary by factors. As Steers (1977) points out: There are 4 sets of variables 
related to effectiveness: (1) organizational characteristics, (2) environmental characteristics, (3) employee characteristics, (4) management policies and practices. In various studies, it turns out that these variables play an important role in facilitating the creation of an achievement-oriented work environment.

Measurement of effectiveness in its development undergoes the discovery phases, but the analysts of the organization agree that the most widely used criteria for measuring effectiveness are: adaptability - flexibility, productivity, job satisfaction, profitability, resource search (Steers).

- Flexibility; is the organizational ability to change its standard operating procedure if its environment changes, and to prevent the occurrence of freezing of environmental stimuli.

- Productivity; assessed in quantity from the product or service produced. This productivity can also be divided into three levels: Individuals, groups, and entire organizations. In productivity measurement there is no cost and output calculation.

- Job satisfaction ; namely the level of pleasure one perceives for its role and occupation in various work situations and organizational developments, as evidenced by the receipt of appropriate remuneration.

- Profitability; means income (can also out-put) on the investment used to run the organization. It can also be seen from the amount of resources remaining after the costs and other resources have been met.

- Search for resources; is intended to the extent that the organization performs all its essential tasks or achieves its objectives, utilizing resources efficiently.

If we note the five criteria of organizational effectiveness it also raises a different view. This concerns about: 1) which criteria are considered important and greatly affect the continuity of the organization, and 2) whether the criteria is appropriately applied to the types of organizations ?. Based on the difference, the most important of all is that any attempt to assess the current level of organizational effectiveness should be preceded by a careful analysis of possible limitations that may not be separated from any evaluation effort. The analysis carried out early before the measurement, is the act of identifying several factors related to effectiveness.

\section{Government Effectiveness}

The effectiveness of an organization is seen as achieving the goals of the organization in general and achieving out-put, growth or productivity that have been determined and achieved together. The achievement of organizational goals is also inseparable from the consistent organization of the tasks and functions. If such a limitation of organizational effectiveness, then in the context of government organizations can be interpreted that the parameters of government effectiveness is a. the fulfillment of the main duties, functions and roles of government bureaucracy appropriately and correctly, and b. the creation of good governance.

The main tasks and functions of government bureaucracy as proposed by Agus Dwiyanto (2005: 378), can be distinguished on three, namely Making policies and regulations, Conducting services, and Forcing the compliance with existing laws and standard norms. These key tasks and functions are important to do because different tasks and functions will create different opportunities and constraints in developing strategies and policies. The distinction does not also make the organization unit stand alone, apart from coordination and integration with other organizational units. The roles played by government bureaucracy are from regulative, protective, redistributive, subsidizing communities to undertake the desired activities of the government (distributive), to the role of public service delivery (public service). The overall role indicates that government bureaucracy can not be separated from public life, or in other words government bureaucracy still dominates almost all aspects of community life.

While governance as defined by UNDP (1997) in Sumarto (2003: 3) "Governance includes the Government the private sector - and civil society - as well as the interaction between the three elements". Furthermore, in its policy document UNDP identifies the characteristics of good governance, which include all, transparent and accountable, effective and equitable, ensures the rule of law, ensures that political, social and economic priorities are based on the consensus of the community, poor and weak in the decision-making process regarding the allocation of development resources. From the formulation and characteristic it can be interpreted that the activity of arranging a good governance must be based on the principles mentioned so that the government become more efficient, responsive, accountable and free from the practice of Corruption-Collusion-Nepotism, and fair. Because the principle is inherent in every aspect of government bureaucracy life, then inevitably efficiency, responsiveness and accountability must always be improved and developed. The aim is none other than to ensure the achievement of good governance.

Based on the parameters of effectiveness of the above government, the bureaucracy is as a tool of government work to spearhead to carry out government tasks in achieving development goals and providing public services. This is evidence that the position of local government is very strategic in serving the public, so the Head of Region must be professional and effective in carrying out government and populist missions. The effort of the Regional Head to organize the government effectively is by realizing the commitment to perform a satisfactory public service. This is not easy to implement. Purwanto (in Dwiyanto, 2005: 179) states "To realize the 
commitment to perform a satisfactory public service is not something that is easy to implement. This is because the government bureaucracy in the region over the years has internalized the old values such as paternalism, priyayi mental, mental pangreh, and so forth that are far from the principles of good governance. Even more extreme, the old values actually encourage the emergence of bad governance practices that grow the behavior of corruption, collusion, and Nepotism. For this reason the Head of Regions needs to prepare new innovations so that every government bureaucracy activity is always on the path of achieving the goals / goals of effective and efficient government.

\section{RESULTS AND DISCUSSION}

To realize the effectiveness of government, then some innovations that can be done, among others:

1. Compiled policies; agreed and established jointly between the Head of Regional and DPRD.

The Regional Head has the main duty of making micro policies as a translation of the macro policies made by the DPRD, and the DPRD is tasked with making macro policies in the form of regional regulations or other regulatory provisions. For the sake of service to the community, the Head of Region and DPRD shall cooperate in preparing policies for the progress, welfare and interests of the regions and the community. A policy that will be determined, according to Utomo (2009: 44), the policy needs to be focused on four strategic issues, namely institutional development, apparatus resource development, Net working, and development of a conducive environment (Suistainable).

2. Compiled policies; in accordance with the will of the people and can be implemented into reality, so that the results can be felt by the people.

One way to encourage the implementation of this innovation is to involve citizens in the policy-making process. Involvement of citizens in the policy-making process is actually a lot of benefits gained. Firstly: the improvement of the quality of the resulting policy, Second: As revealed by Smith and Ingram (1993) in Dwiyanto (2005: 190), in addition to bringing benefits to society, public participation in the policy making process will also benefit the government, become stronger in the sense that there is an increased institutional capacity in policymaking. Similarly, Webler, Kastenholz, and Renn (1995) in Glicken (2000: 302) - quoted from Dwiyanto (2005: 190) Webler, Kastenholz, and Renn (1995) in Glicken (2000: 302) - quoted from Dwiyanto (2005: 190); Jones (1996: 70); Denhardt and Denhardt (2003: 50); Dunn (2010); Xuan Zhang (2014); Robert Jupe, Warwick Funnell (2014); Terry Flew (2014); Alexandru V. Roman (2015). - that public participation in the decision-making process would be profitable; contribute to the increased competence of decision-makers through the development of quality policy making, providing greater legitimacy to decisions made because public participation can improve public accountability in decision-making processes, and provide a positive image as a democratic society. More importantly, through public participation in the policymaking process, citizens can help to increase the assurance or certainty that the voices and interests of individuals and groups in the community are heard and responded to by the government fairly (Denhardt and Denhardt, 2003: 50).

3. Local policy alignment with the center.

Dissatisfaction between regional and central policies always occurs. Suppose related to the simplification policy of investment permit. From the center mentioned there is a simplification of permits, but not in sync with the area so that investors are complicated in the handling of licensing in the field, especially the permits handled by the local government (Kompas, 30/04/2016).

Innovation harmonizes regional policies with the center aims to smoothen and synchronize the achievement of national goals, so as to create a uniformity in its implementation. But in an effort to harmonize the central policy with the regions, keep in mind must be with the situation and conditions of the region. Different cultures, local, geographical, and economic values in different regions give rise to different needs, which ultimately require different policies. Kumorotomo (2005) in Sugandi (2011: 125), once explained a few things about why many policies, programs and public services are less responsive to the aspirations of the people: First, most bureaucrats are still oriented to power rather than to the public interest. Bureaucrats place themselves as rulers according to the paternalistic philosophy. Secondly, there is a wide gap between what policy-makers decide and what people want.

To create harmony between central and regional policy, a Regional Head must establish relationships and strengthen Government Communication. As stated by Hasan (2005: 95) "In the working relationship is known existence of communication information and communication work relations. Information communication is usually conveyed by the chairperson to the work units underneath it through apple work or in a meeting setting, whereas workplace communication is a way of conveying the activities that must be carried out in order that the activity can be managed efficiently and effectively ". The same thing Gondokusumo (1980: 2) has pointed out, communication activities that exist in working relationships generally aims to: (1) improve work relations and cooperation between organizations or departments, (2) knowing as early as possible the problems that arise in the implementation work, (3) reduce the negative aspects of conflict, and (4) encourage morale. 


\section{Transformative political leadership,}

Transformative leadership as outlined in Pasalong (2008: 128) with Transformational leadership terms consisting of leadership and transformational. According to him, leadership is a style (way or technique) used by leaders in influencing followers or subordinates in cooperating to achieve the goals that have been determined. While Transformational is to change things into another form. So he thinks transformational leadership is how to transform followers toward organizational development. While Bass (in Gibson, Ivancevich, et.al, 1997: 86) states "Transformational Leadership is the ability to inspire and motivate followers to achieve results that are larger than originally planned and for internal rewards"

Therefore, with this transformational style, the Head of the Region can do so by: raising awareness of resources on the importance of their respective roles, directing them to stay focused on shared interests and goals (regional visionmission), building interactions and partnerships together according to their roles respectively, and develop the potential of employees, communities, and stakeholders optimally in implementing local policies and programs. But keep in mind, when the Head of the Region will apply this transformational leadership in governance and to achieve its success then at least there are some principles that must be considered. (1) clarity of vision, (2) employee awareness, (3) achievement of vision-oriented vision, (4) pioneers of change, (5) development self, (6) employee learning, (7) empowerment of employees, (8) creativity development, (9) cultivate cooperation, and (10) organizational kondusifitas. By knowing these principles, the Head of Region in applying transformational leadership has been able to prepare itself in its capacity as regional leader, not the leader of a particular group or group

5. Management control of work plans and programs.

Against this innovation the Head of Region can not rule out the importance of compatibility aspect or compatibility and sensitivity. Utomo (2009: 81) asserted "... because Governance within the framework of regional autonomy, macro requires the compatibility between the government private - and community, while the micro within the local government demanded compatibility among the existing components in government ". Strengthening the compatibility between these components is necessary because the ultimate goal is the creation of partnership relationship with the Head of Region with all components of the macro and micro government. The Regional Head must be aware that his duty to establish the region and its people through work plans and programs, and to achieve that can not be done alone without through partnership with other components. Compatibility can not only be done with communication, negoisasi and interaction, but also the concern of the Head of the Region on the function, mission and main task. So the work plan and strategic program that exist in the scheme of regional planning is a guide for all components in the region.

If compatibility is directed to external relations of the Head of Regions, the sensitivity is directed to the internal sensitivity of a Regional Head towards the existence of the regional environment, especially the sensitivity to the available potentials of the region. Because through this sensitivity will emerge strategic analysis of Head of Region to develop area potency.

\section{CONCLUSION AND RECOMMENDATION}

\section{A. Conclusion}

Based on the description on the introduction and discussion, the authors conclude:

a. Innovation to realize the effectiveness of government needs to be designed by the Head of Region oriented to the achievement of effective results. The need for innovation, considering the Head of Region as a political official (politician) usually tends to have a short and narrow orientation based on momentary political interests. With the innovation, it is expected that the performance of the Regional Head in managing the government will be more controlled and the effectiveness of the government can be achieved, so that public service estuary will be more clearly measured rationally.

b. To realize the effectiveness of government, then some of the innovations that can be done include: (1) the policy is prepared; agreed and established jointly between the Head of Regional and DPRD, (2) the policy prepared; in accordance with the will of the people and can be implemented into reality, so that the results can be felt by the citizens, (3) harmonious regional policies with the center, (4) transformative political leadership, and (5) Management control of work plans and programs.

\section{B. Recommendation}

To encourage the innovation to be realized in realizing the effectiveness of government, the authors recommend that the Head of Region:

1. Synergize with the DPRD in drafting policies focused on four strategic issues namely institutional development, apparatus resource development, network development, and development of a conducive environment (Suistainable).

2. Involving citizens in the policy-making process, as it will improve the quality of the resulting policy, bring benefits to the community, and the government will become stronger in the sense that there is an increased institutional capacity in policy-making. 
3. Establish and strengthen Government Communications through a model of employment communication.

4. Develop compatibility or compatibility behavior and Sensitivity

\section{REFERENCES}

[1] Bass, Bernard M, Leadership : Good, Better, Best, Organizational Dynamics, 13, 26 - 40, 1985

[2] Denhardt, J.V and Denhardt, R.B, The New Public Service : Serving, not Steering, Armonk, etc: M.E. Sharpe, 2003.

[3] Dwiyanto, Agus, Mewujudkan Good Governance Melalui Pelayanan Publik, Yogyakarta: UGM-Press, 2005

[4] Gibson, James L, Ivancevich, John M. Donnely Jr. James H, Organisasi dan Manajemen, Perilaku Struktur, Proses, Alih Bahasa Wahid Djoerban, Jakarta: Erlangga, 1990.

[5] Gondokusumo, A.A, Komunikasi Penugasan, Jakarta: Gunung Agung, 1980

[6] Hasan, Erliana, Komunikasi Pemerintahan, Bandung: Refika Aditama, 2005

[7] James, A. Gibson, James L, dan Ivancevich, John M. et.al, Organisasi, Struktur, Proses, Alih Bahasa Nunuk Adriani, Tangerang: Binarupa Aksara, 1997

[8] Organisasi, Struktur, Proses, Alih Bahasa Nunuk Adriani, Tangerang: Binarupa Aksara, 2007.

[9] Kei Ho, A.T and Coates, P, Citizen Participation: Legitimazing Performance measurement as a Decision Tool ", Goverment Finance Review, April, 2002

[10] Pasalong, Herbani, Kepemimpinan Birokrasi, Bandung: Alfabeta, 2008

[11] Sedarmayanti, Restrukturisasi dan Pemberdayaan Organisasi Untuk Menghadapi Dinamika Perubahan Lingkungan, Bandung: Mandar Maju, 2000

[12] Steers, Richard M. Efektivitas Organisasi, Goodyear Publishing Company, Inc - LPPM dan Penerbit Erlangga, Jakarta, 1985

[13] Sugandi, Yogi Suprayogi, Administrasi Publik - Konsep dan Perkembangan Ilmu di Indonesia, Yogyakarta: Graha Ilmu, 2011

[14] Sumarto, Hetifah $\mathrm{Sj}$, Inovasi - Partisipasi - dan Good Governance, Jakarta: Yayasan Obor Indonesia, 2003

[15] Utomo, Warsito, Administrasi Publik Baru Indonesia : Perubahan Paradigma dari Administrasi Negara ke Administrasi Publik, Yogyakarta : Pustaka Pelajar, 2009

Journal

[16] Alexandru V. Roman, The Determinants of Public Administrators' Participation in Policy Formulation, Jorunal of American Review of Public Administration, 2015

[17] Robert Jupe, Warwick Funnell, Neoliberalism, consultants and the privatisation of public policy formulation: The case of Britain's rail industry, journal home page:www.elsevier.com/locate/cpa, 2014

[18] Terry Flew, Academics in the Policy Process, Journal of Information Policy, Vol. 4, 2014

[19] Xuan Zhang, Study on the participation of citizens in public policy formulation, Applied Mechanics and Materials Vols. 687-691 (2014) pp 5128-5130 Trans Tech Publications, Switzerland, 2014

\section{Newspaper}

[20] Kompas, 31/03/2016, Calon Perseorangan dan Pemda

[21] Kompas, 20/04/2016, Selaraskan Kebijakan di Pusat dan Daerah 